International Journal of Social Science And Human Research

ISSN(print): 2644-0679, ISSN(online): 2644-0695

Volume 04 Issue 12 December 2021

DOI: 10.47191/ijsshr/v4-i12-08, Impact factor-5.586

Page No: 3506-3508

\title{
The Role of Amir Temur's Way of Life as an Example in Educating Young People in the Spirit of Military Patriotism
}

\author{
Dilshod Abdukahorovich Bobomurodov \\ Major, Department of “Aviation Armament”, Higher Military Aviation School of the Republic of UZBEKISTAN
}

\begin{abstract}
The life of our great ancestor Sahibkiran Amir Temur, his military tactics, the ability to unite scattered patriotic amirs and beys, to unite in a military group and form a military unit, as an example of educating students in the spirit of military patriotism. wide application and use of a wide range of information will be expedient.

Every citizen of independent Uzbekistan grows up to be a loyal, intelligent, strong-willed, deep-thinking and understanding, sharp-witted, a fearless warrior, a patriot and a just defender of the country in schools our great commanders must study deeply the paths they have traversed.
\end{abstract}

KEYWORDS: Zanjir-sara, spy, jatta, hiraj, soldier, yalovbayrak, commander, centurion, captain, ulufa, sitam, judge soldier, military tactics, leader listener, patriot, higher education institution, rule of law.

\section{INTRODUCTION}

The study of the life and work of Sahibkiran Amir Temur in the subject "History" is reflected in primary, secondary and higher education institutions.

From his childhood, Sahibkiran Amir Temur grew up to be agile, courageous, strong-willed and patriotic.

It is well known from history that Sahibkiran Amir Temur, who received the tradition of wrestling and hunting from his childhood, was brought up in the spirit of patriotism. He grows up to be a strong, stocking boy. The chain draws water forty times from the well where five or six servants draw water from Sarah's well. Gradually, people were amazed and took the collar to the level of a handful.

\section{THE MAIN RESULTS AND FINDINGS}

He was trained by special trainers in horseback riding, archery, several exercises and military games. Amir Temur was a heavy, calm, deeply thoughtful and intelligent person by nature, and he was extremely intelligent, quick to understand the abilities, virtues and sincerity of people. As a result, he was able to attract loyal friends from his peers with his leadership skills as a teenager.

His childhood friends and classmates Abbas Bahodir, Jahonshohbek, Inoq, Sulaymonshohbek, IdukiTemur, Sayfuddinbek, Hindushoh, Qarqara and other military patriots gathered and trained together, participated in competitions, gradually became soldiers and joined a military group and formed a military unit. In group exercises, Amir Temur told the group to fight until they had a fair, parental duty and if necessary, their last strength. He was able to properly apply incentives and disciplinary action at the right time. Because at the heart of it was the goal of getting rid of the Mongol invasion. Amir Temur began his first military career the service of some regional emirs with his soldiers.

Between 1365 and 1370, the most instrumental problems facing Sahibkiran in the formation of the state were:

1. First of all, to completely liberate Movarounnahr from the oppression of the Mongols, to reconcile with it.

2. Giving Amir Hussein the province he wants and keeping it under control.

3. To form a "puppet" government in various provinces and to subjugate the emirs who scattered Movarounnahr.

4. Strengthening the borders of the country, the choice of the capital, and develop this capital.

5. Organize the army, deal with everything from food to the payment of soldiers.

Amir Hussein (Barakkhan) repeatedly insulted the young Amir Temur. But still Amir Temur will support him. The reason was that Amir Hussein (Barakkhan) had to play a mediating role in the expulsion of the Mongols in these lands. The mastery of the Sahibkiran in military work is seen in the combination of intelligence and courage. He does things that no one else has. As a spy, he and his friend Inaq go to the enemy's side and join the army. Gung himself, crows and brings information about enemies. Thorough measures are strengthened in such a risky way ... 
By the 1370s, Amir Temur's authorityhad greatly increased. This will allow him to formally seize power, soon. All the amirs and beys go to his service. Everyone swears to serve him. In particular: Movaunnahr, Tashkent, Khojand, Khokand, Marginon, Andijan, Kashgar and Turkestan will be liberated from the tyranny of Jatta.

People were strongly opposed to surfing taxes. He later exempted his nation from taxes many times. More importantly, blindness and cascading are not allowed in the collection of taxes, but those who personally received the tax by the decree of Amir Temur, depending on the harvest, soil fertility and other conditions, even pay their personal property to the treasury at the expense of the people. His wife, OljoyTurkon, also stole gold and silver jewelry.

One of the features of Amir Temur's marches is that he tried not to carry out the work before the battle in order to keep his warriors as healthy as possible. He leaves the rulers of the country, who have welcomed him with kindness, in their place. If he did not keep his word, he brutally punished, expelled, and executed the landowners who conspired with treacherous rivals.

In order to support the activities of Sayyid Baraka Amir Temur, the symbol of the Supreme Power presents him with a drum and a beggar. In this way he can unite from commanders to ordinary soldiers.

He was not hurry to fight the Ottoman Sultan BoyazidEldirim, who was powerful at the time, but instead advocated improving relations with the sultan and sent ambassadors four times. Each time, BoyazidEldirim said inappropriate words due to stubbornness and arrogance. Later, when BoyazidEldirim was taken prisoner, he was honored and brought to the palace. And mercy is shown to their children.

During the march, those in the army who did not obey the commands of their superiors were severely punished. The command of the commander was imposed on the centurion, the centurion on the captains, and the captains on his subordinates, and those who did not comply were punished. Among both the military and the subjects, the duties of the chiefs were to punish the disobedient, to drive out those who failed to perform their duties, and to elect others in their place.

\section{INCLUDING}

- Those soldier who turn their backs on any war and run away, and deprive it of its favor;

- Those soldier who accepted the apology if forced to withdraw;

- Thosesoldier who insulted him if he panicked;

- Thosesoldier who ran after the wounded with a sword in front of the enemy, praised him and took note of his wounds;

- Those soldier who received useful advice from them on how not to deprive him of his rank and demotion when he reached old age.

The qualities of the Uzbek people, such as: patriotism, humanity, humanism, justice, hospitality, respect for the elderly, respect for the young, today occupy a strong place in our consciousness on the basis of spiritual and moral values. The good feelings in the hearts of our young people, such as kindness, generosity and honesty, aspirations to faith, show that they are spiritually mature, knowledgeable, enlightened, engaged in creative work, armed with the national idea, national ideology.

The task and content of the formation of patriotic, just and humane education is carried out on the basis of adherence to the basic principles and pedagogical conditions of national moral education in primary, secondary and higher education institutions.

The wisdom of the great master Amir Temur "Power is in justice" has been occupying a large place in the life of our people for centuries. Friendship, brotherhood, solidarity, patriotism, courage and humanity, which are the basis of this humanitarian idea, embody the qualities of the Uzbek people. These words of Amir Temur about patriotic justice are of great importance today and are aimed at strengthening and protecting the independence of Uzbekistan, educating young people in the spirit of patriotism, raising the dignity of our country, building a free society ruled by honesty and piety. That is why he preferred one day of justice to a hundred days of prayer.

"Whoever pulled his mind and enthusiasm on the test scales and saw more than others, I would educate him and raise him to the emirate level. I have opened the door of justice in every country, I have blocked the path of oppression sitam," his wisdom calls on everyone to be intelligent, sharp-minded, perceptive, thoughtful and patriotic, to do useful things, both in carrying out their work and in entrepreneurship and in achieving blissful happiness.

Amir Temur not only fought to make the society in which he lived the most mature social system, to build a prosperous life, but also believed that these ideas would be celebrated all over the world. Only for this purpose did he wear a military uniform. He warns that every head of state who has fought for such purposes must remember four basic things: first, to act with the right decision and council, whichever country he intends to conquer; second, to think carefully and vigilantly and carefully in each case in order to avoid making a mistake; thirdly, to gather and unite around him the noble patriotic landmen (amirs); and fourth, not to leave today's work for tomorrow. In Amir Temur's program and political and legal views, it is more obvious to dream of a perfect society, to realize it and to take responsibility for it. Therefore, the peculiarity of Amir Temur as a statesman, commander and thinker is that he built a perfect society in the image of the kingdom (empire) he ruled and tried to strengthen it in every way. An important aspect of Amir Temur's political doctrine is the rule of law in governing society. The main condition for governing the reign of Timur was the recognition of the supremacy of law over all deeds and the creation of its basic rules. In Timur's conclusion that the principle of the rule of law is a necessary condition, the rule of law is very deep. 
Amir Temur in his life and activity carefully examined every conflict and problematic case. He tried to solve them as correctly as possible. He acted with justice and fairness in all his dealings. He was strict with his troops, demanding, and merciful to his subjects. He gave a lot of charity to the poor. He forgave the sins of sinners. As a result, his power increased. The content of Amir Temur's life, along with justice, was formed by a sense of honesty and faith, the criterion of religion. Although he ruled over half the world, he believed that power was important not in violence, but in justice and patriotism.

The statue of our ancestor Amir Temur has a symbolic meaning. In it, Amir Temur seems to be pulling the reins of a running hors. He stretches out his hand without a sword and wishes peace to the peoples of the world. "Power is in justice!"

Spiritual, moral and spiritual experience creates ample opportunities for the implementation of relations between society and the population in a single, integrated state based on justice and harmony. In the meaning of the word justice, patriotism, purity, honesty, truths are embodied.

Legal disputes arising from military legal relations between soldiers were considered and resolved by a judge-military court.

Mankind has always valued its homeland. The patriotic countries prospered and the people were free. Lands that were unprotected were trampled underfoot, corruption reigned, and society fell into disrepair.

A patriotic, just man will have a sharp mind. He thinks correctly and clearly. Being pure in heart shows that he is noble and courageous. Being fair means keeping your word.

Only a patriotic, just person lives as a nation, he considers it a blessing to be kind to others, to help those in need and to show the right way.

Sahibkiran's great qualities, such as patriotism, justice and military tactics, are widely taught as a textbook in higher education institutions of the most developed countries of the world.

\section{CONCLUSION}

Amir Temur, who was always ready to give his homeland, the sacred land of his ancestors, his whole being to his homeland, was a skilful, courageous fighter, strong-willed, courageous warrior, rider, ability to shoot from a bow, and finally We should use his life as a model in educating our youth in the spirit of military patriotism. necessary. Only then can we nurture true young sharp-witted patriots.

\section{REFERENCES}

1) Timur regulations. From the Persian language Alixonto'raSaguni and H.Karomatov translation.// East star, 1989, №8.

2) RuiGonsales De Klavixo. Diary of travelling in Samarkand to Timur's palace . (1403-1406 years) Scientist I.S.Mirokov. - Moscow: Science, 1990 year .

3) Saladin Toshkandy. Timurname. Tashkent "Chulpon" 1991 year.

4) 4.Sharafiddin Ali Yazdi. Victory. "East star" 1992-1993 year.

5) Muhamadjonov M. Amir Temur and the Kingdom of Temurids. - Tashkent: chief editor of Encyclopes. 1994 year.

6) Ivanin M. Two great commanders. Genghis Khan and Amir Timur. - Tashkent: treasure, 1994.

7) Sharafiddin Ali Yazdi.Victory, translation into uzbek language Dervish Ali al Bukhoriy translation . - Tashkent:" Shark " 1997 yil.

8) Akhmedov B. Amir Timur lesson. - Tashkent: Vostok, 2000.

9) Uvatov U. Great people of great countries . Tashkent" Uzbekistan " 2018.

10) Shamsutdinov R., MuminovH.History of Uzbekistan. Tashkent "Akademit chapter " 2019.

11) Eshov B. The Uzbek state and thehistoryof national government. Tashkent "New centenary " 2019. 